\title{
The EAEU Cooperation and Integration Processes on Oil and Gas Markets
}

\author{
Igbal Guliev, Ekaterina Krivosheeva, Geladze Shota, Christina Benashvili \\ Moscow State Institute of International Relations (University) of the Ministry of Foreign Affairs of the Russian Federation \\ (MGIMO University) \\ Moscow, Russia
}

\begin{abstract}
The article covers the recent tendencies on the energy markets of the EAEU countries and is aimed at developing better strategies for their development and integration. The article reveals the main problems of the current strategies and the issues in the economies of the EAEU countries in the energy sphere. The authors developed an inclusiveness index, allowing to estimate whether the strategy of integration of energy markets in efficient or not. The recommendations given in this article are of a complex character and mostly refer to the improvements in the integration strategies of the EAEU countries. The novelty and the scientific significance of the paper comprise the index development, the analysis of the strategic energy integration documents and the institutional analysis of energy market of EAEU.
\end{abstract}

Keywords-oil and gas markets; EAEU; cooperation; single market

\section{INTRODUCTION}

The oil and gas markets are one of the most developed markets in the EAEU countries. The revenues, received from the production of oil and gas in the leading EAEU economies are significant. Due to the Decision of the Eurasian Commission "On the formation of the single oil and gas market of the EAEU" the theme of energetic integration in the Eurasian Union has reached a new level. Before the adoption of this document in 2016, the model of energetic cooperation on the territory of the EAEU was led by one general idea - the leading companies, which exported energy resources (mainly from Russia and Kazakhstan) conducted their own policy on the prices of goods and the logistics used to transport them to the final destination. Because of that fact, Armenia, for instance, had more possibilities of importing gas and oil from Azerbaijan. In the context of the decision, the new situation can change a lot on the markets of the neighbor to the EAEU countries.

The new tendencies of tighter cooperation in the sphere of refinery of oil arise. In addition to that, the strong price pressure on the exporters of oil and gas leads to their orientation on the local market, where their products can be much more competitive, than on the foreign markets.

The main aim of this article is to reveal the main tendencies of creating a single oil and gas market on the territory of the EAEU, pinpoint the issues, which the Eurasian Commission will face during this process in the future and give prospects of the consequences of this decision. In addition to that, the recommendations on the development of the institutional cooperation will be given. These tasks are to be conducted on the base of the statistical method and the analysis of the current legislative base for energetic cooperation in the EAEU. We will partly mention the electric grids of the countries as a part of the energy infrastructure and cooperation in the EAEU.

\section{METHODOLOGY}

Within this article, we stick to the structure: problem current situation (statistical data) - solutions proposed in comparison with the steps taken. The article offers the propositions for the problems revealed, based on the study of program documents of the EAEU and the statistical data.

The authors introduce an inclusiveness index, which allows to estimate the centralization of the EAEU energy market, based on the study of its members' markets. The index comprises 4 main components of the index allow to estimate the exports and imports of the EAEU countries, not including the energy trade balance, as in the EAEU several countries do not export, or import oil or/and gas. This approach allows to exclude the zero data and receive a more statistically correct result.

Oil and gas markets in the EAEU are tightly connected with energy balance, which includes electric energy infrastructure, however it is not in the focus of the research. The electric energy market of the EAEU is mentioned in this paper only in the aspect of its connection and influence on oil and gas markets development.

Due to the tight connection of energy sphere with the investments and international politics, we could not avoid mentioning several development banks, which can contribute to the development of energy infrastructure in the EAEU.

\section{OVERVIEW OF THE CURRENT TENDENCIES ON THE ENERGY MARKETS OF THE EAEU}

First and foremost, the Eurasian economic integration is considered by the main actors of the integration, namely, Russia and Kazakhstan, as one of the strategic initiatives on the way of their economic development [1]. Recently, Kazakhstan is reconsidering its position and turning towards tighter cooperation with China in its Belt and Road Initiative (BRI). 
The consequences of such actions of the EAEU members may be fatal for the Union, so it is important to point out the key issues on the way of energy integration process in EAEU [2]

1) The main supplier of oil and gas resources in the Union is Russia, the other countries are net-importers of energy resources, which leads to the high volume of energy trade. Due to historic dependency on the Soviet supply of energy, the former Soviet countries, which form the EAEU, tend to develop such dependency on Russian exports, which in turn, leads to high costs for their budgets. During the existence of the USSR, the prices of oil and gas for the republics of the country were significantly lower, in the Post-Soviet era the same tendencies were preserved up to the 2012, when the Russian economy fell into crisis and the country needed additional financial resources. The export prices then raised and equaled to the global prices level. It causes extensive discussion and protest in the other EAEU countries [3].

2) The Russian refinery industry is rather weak and it exports its hydrocarbons to Belarus, where the mighty refinery facilities are situated [4]. The export and then import of oil products cases the prices rise in Russia and on the EAEU market in general, which forces some of its members, for instance, Armenia to focus on Azerbaijan oil exports, rather than on the Russian ones, forming tension between the members of the Union.

3) The energy technologies are numerous and many of them are fundamental. Their development is costly, so it is often much cheaper to import them, or use the leased machinery and facilities. It is absolutely true for the EAEU countries, where Russia possesses the most important energy technologies, while other countries rely on the Soviet heritage and on the development of their infrastructure by more mighty partners, for instance, PRC or Russia. The investments in the area have high returns, so many foreign investors are ready to provide financial resources. The countries (and companies) that possess the fundamental technologies strive to gain numerous benefits from their position, leading to inferior positions of the energy technologies non-possessing economies of the EAEU.

4) The current actions of the Russian energy authorities, which change the fiscal system in a way that export duties on hydrocarbons are incorporated in the natural resources extraction tax lead to higher prices of the hydrocarbons on the EAEU energy market and building the barriers for further integration.

The strategy of creating a single energy market in the EAEU is aimed at unification of the legal approaches to the oil and gas trade and stimulation of the intra-EAEU trade of energy. The main goal of it can be expressed as: building a common approach to energy trade, creating a legal act on it and receiving all the benefits it can provide. This approach is oversimplified and does not take into account the following factors:

- The oil prices fluctuation. It may be cheaper for the members of the Union to sign contracts with the Persian
Gulf countries, which produce light oil (when the majority of Russian oil is heavy - Urals, for instance), and find other cheaper energy resources, especially in the context of BRI, connecting the discussed regions by a tight vertical and horizontal infrastructure and providing trading mechanisms and financial support (Asian Infrastructure Investment Bank, for instance) The analysis of oil prices based on [5] demonstrate that in July 2019 the Urals and OPEC basket oil prices equaled, which gave opportunities for the OPEC countries with cheap oil to conquer the EAEU oil market.

- The political conjuncture of the EAEU trade. Some of its countries (Kazakhstan and Kyrgyzstan) tend to cooperate with China, some (Armenia and Belarus) with the EU). The EAEU is stable and develops with a high pace until Russian economy is strong and can provide benefits for the members of the Union.

- Alternative energy resources. All the countries of the EAEU, except for Belarus, possess high potential of alternative energy generation [6].

- The gas market of the EAEU countries is monopolized by several Russian state-owned giants (such as Gazprom), which dictate their conditions.

All in all, the strategy of the development of the energy industry in the EAEU has a number of structural issues and is not developed yet. The further steps, offered in this article are aimed at elimination of the problems in the strategy, mentioned above.

In order to estimate the inclusion of the country of the EAEU in the Union on the level of energy integration, we offer an inclusiveness index (InIn):

$$
\operatorname{InIn}=\frac{\frac{O I_{E A E U}+O E_{E A E U}}{O I_{T}+O E_{T}}+\frac{G I_{E A E U}+G E_{E A E U}}{G I_{T}+G E_{T}}}{4-n} * 100 \%,
$$

where $O I$ and $O E$ are oil import and export, $G I$ and $G E-$ natural gas import and export, $n$ is the quantity of zero trade inputs and the index $T$ stands for total.

Table 1 presents the data for the EAEU countries.

TABLE I. INCLUSIVENESS INDEX FOR THE EAEU COUNTRIES (CALCULATED BY THE AUTHORS, BASED ON [7-8]

\begin{tabular}{|l|l|}
\hline \multicolumn{1}{|c|}{ Country } & \multicolumn{1}{c|}{$\begin{array}{c}\text { Inclusiveness Index by the latest } \\
\text { data (2017) }\end{array}$} \\
\hline Russian Federation & $55.58 \%$ \\
\hline Kazakhstan & $60.39 \%$ \\
\hline Belarus & $66.79 \%$ \\
\hline Armenia & $74.07 \%$ \\
\hline Kyrgyzstan & $50.00 \%$ \\
\hline
\end{tabular}

The overall inclusion of the countries in the Eurasian energy market is relatively low, still, there are a number of remarkable results. First of all, Russia despite it is low InIn tightly cooperates with the EAEU countries in its hydrocarbons exports $-55.58 \%$ of its very high exports is a significant number. Secondly, Armenia tends to cooperate with the EAEU 
despite the possibilities of cooperation with Azerbaijan, described earlier, Kyrgyzstan remains lowly included in the Eurasian energy market, the only reason for it is the cheaper cooperation with China [9].

\section{THE POSSIBILITIES FOR TIGHTER COOPERATION FOR THE EAEU (ELECTRIC ENERGY ANALYSIS INCLUDED)}

The EAEU electric energy infrastructure is relatively highly developed and covers all the territory of the EAEU. Armenia was the last to join the single electric grid in 2019. The overall situation in the electric energy generation and distribution in the EAEU is stable and requires minor improvements. First of all, it is notable, that the main suppliers of the EAEU economies are their national producers of electric energy. The overall mutual trade in electric energy in the EAEU equals to 6.1 billion $\mathrm{kWh} * \mathrm{~h}$ [7], which is a significant number, but derives mainly from Russian exports of energy resources to border regions of Belarus and Kyrgyzstan.

There is another direction of development of the industry, that will allow to provide drivers for economic development of the EAEU economies. It is the creation of single electric grids with the neighbor non-EAEU countries, these are Iran, Tajikistan, Georgia and others. This will allow to conquer new energy markets and contribute to economic development of energy industry in the EAEU.

The only problem, that electric energy sphere of the EAEU faces is the weariness of the infrastructure and facilities. The modernization requires financial resources, which can be received through the proliferation of energy infrastructure to the named countries. The Project requires large investments, which can be received from the Asian development banks, such as AIIB and the Asian Development Bank. It is a good idea to attract the New Development Bank to these projects and manage the financial resources through the EADB. This scheme will contribute to better development of energy infrastructure in the EAEU, better financial situation in the economies of the Union and better position of the EAEU itself and its financial institutes on the global arena.

Currently, the main strategic document for the intra-EAEU cooperation in the sphere of energy is aimed at the horizon of 2025 in establishing a single energy market. The problem (in addition to the mentioned ones) is, that EAEU does not have that time. The Chinese BRI initiative and its victorious introduction in Asia and Europe endangers the EAEU cooperation in energy distribution by cheaper finance and higher possibilities of energy infrastructure development, proposed by the Chinese companies. The key features, which can make the situation for the EAEU better are connected with higher integration pace and mighty drivers of integration process.

1) The first possibility is to establish a single EAEU energy information and financial derivatives market. It will allow to find a common ground in energy information standards and lead higher inclusiveness in the energy market of the national energy companies and suppliers. This initiative can be realized on the base of the Moscow Stock Exchange, and will consequently lead to centralization of the energy information services. In addition to that, this step will allow to overcome another serious problem of energy integration, namely the misunderstanding about oil and gas prices. The single oil and gas prices authority with good reputation in the EAEU can put an end to the price controversies in the Union. This step requires high political will to overcome the current problems. Another step in the same direction is establishing the single authority to monitor the production and consumption of oil and gas in real time. This will allow to: firstly, avoid breach of fiscal laws by the transnational corporations (which tend to imply transfer prices in order to report lower revenues), and help the oil trading companies to find suppliers. Secondly, it will help cut down the logistics costs of gas and contribute to the better estimation of energy resources, needed by the EAEU members. In addition to that, such authority will have the instruments to estimate the decentralizing tendencies in the EAEU through the monitoring of the InIn in real time.

2) Secondly, the unification of standards of oil and gas quality and ecological standards, proposed in the Program, is to be conducted with the participation of the most significant players of the energy refinery market of the Union. It serves several tasks: the expert opinion of the most economically reasonable composition of oil products, the discussion of technological tracks of cooperation and the search of possibilities of neutralizing the negative impact of the tax reform in Russia. The technological cooperation, proposed through such mechanisms may contribute to higher access to the fundamental energy technologies, creation of the research centers etc. The supranational discussion of the Russian tax reform impact on the EAEU economies seems unprovable, still the discussion of the issue in the scientific and economic community may bring positive effects for all the parties of the problems.

3) Thirdly, the creation of single development strategy in oil, gas and electric energy spheres, which are now divided into three different documents. This measure will allow to synchronize them and gain more effect from their implication through the better timing of the steps taken under these strategies.

4) It is very important to create a strategy of alternative energy development under the EAEU. Today the effects of the alternative energy introduction in the economies of the countries are not that significant, however, the financial mechanisms of receiving investments, arising in Asia state the insufficiency of the traditional energy infrastructure investments, concentrating on green energy. Eurasian Development Bank in cooperation with the AIIB can provide significant resources on the development of alternative energy in the EAEU, which in turn will give drivers to its economic cooperation.

5) The introduction of a wider cooperation in the sphere of electric grids will bring numerous benefits to the EAEU economies, as it was mention earlier, however it is an important step towards the creation of strategic balance 
between the EAEU countries and PRC and its satellite economies on the territory of Asia. It will boost not only the economic, but political cooperation in the EAEU.

All the proposed steps allow to enhance cooperation possibilities for EAEU in the sphere of energy production and distribution, leading the participating economies to a better state of being and providing them possibilities for further proliferation of partnership. None of the steps proposed confront the strategies, developed by the Eurasian Economic Commission, they contribute to strengthening the cooperation and improvement of the weak points of the documents discussed.

\section{CONCLUSION}

The energy markets of the EAEU need more actions in order to be considered ready for integration in a single market. These steps are proposed in a number of national documents, and several important steps (such as tax reform in Russia and the proliferation of energy grids through Armenia).

Though, there are many structural problems in the framework of energy cooperation in the EAEU, the external factors contribute to the centralization of the Eurasian economies in order to stand against them. There are several options of the center of centralization, in the energy sphere there are two of them - Russia and China. The main factors, that contribute to it are technological base and the ability to produce natural resources supply (extract them in case of Russia and resell them in case of China).

The main steps to be taken in order to overcome the structural problems of the EAEU comprise the development of high technologies in the sphere of energy, the monitoring of the ecologic component of the industry, the proliferation of unification and the attention to the new sources of energy. The incorporation of these steps into the strategy of the EAEU energy development will allow it to become significantly better The proposed inclusiveness index is to become one of the indices of the successfulness of the strategies. In addition to that, we strongly recommend the formation of the single energy strategy, which will encompass all the directions of the energy cooperation in the EAEU.

Nevertheless, there are numerous threats and risks for the successful implication of the single energy market in the EAEU, which are to be overcome by creation of strong drivers in the economies of its energy core - Russia, Belarus and Kazakhstan.

\section{REFERENCES}

[1] M. Pastukhova and K. Westphal, "A common energy market in the Eurasian Economic Union: implications for the European Union and energy relations with Russia," SWP Comment, 9/2016. Berlin: Stiftung Wissenschaft und Politik -SWP- Deutsches Institut für Internationale Politik und Sicherheit, 2016. Retrieved from: https://www.ssoar.info/ssoar/handle/document/46159

[2] K. Zemskova, "The Common Energy Market of the Eurasian Economic Union. Implications for the European Union and the role of the Energy Charter Treaty (ECT),"2018. Retrieved from: https://energycharter.org/fileadmin/DocumentsMedia/Occasional/1The_
common_energy_market_of_the_EAEU implications_for_the_EU_and_the_role_of_the_ECT.pdf

[3] V. Yermakov, J. Henderson and B. Fattouh, "Russia's heavy fuel oi exports: challenges and changing rules at home and abroad", Oxford Institute for Energy Studies, 2019. Retrieved from: https://www.oxfordenergy.org/publications/russias-heavy-fuel-oilexports-challenges-changing-rules-home-abroad/?v=f9308c5d0596

[4] Ministry of Foreign Affairs of the Republic of Belarus, Belarus refineries increase production output. Retrieved from: http://mfa.gov.by/en/press/news_mfa/a6a2519c106dd654.html

[5] Oilprice.com, Oil Price Charts, 2019. Retrieved from: https://oilprice.com/oil-price-charts

[6] A. V. Bogoviz, S. V. Lobova, Y. V. Ragulina and A. N. Alekseev, "A comprehensive analysis of energy security in the member states of the Eurasian economic union, 2000-2014," International Journal of Energy Economics and Policy, 7 (5), pp. 93-101, 2017.

[7] Eurasian Economic Commission, Mutual energy supplies in 2015 (billion $\quad \mathrm{kWh} * \mathrm{~h}$ ), 2016. Retrieved from: http://www.eurasiancommission.org/ru/act/energetikaiinfr/energ/energo _stat/Documents/\%D0\%92\%D0\%B7\%D0\%B0\%D0\%B8\%D0\%BC\%D 0\%BD\%D1\%8B\%D0\%B5\%20\%D0\%BF\%D0\%BE\%D1\%81\%D1\%82 $\% \mathrm{D} 0 \% \mathrm{~B} 0 \% \mathrm{D} 0 \% \mathrm{~B} 2 \% \mathrm{D} 0 \% \mathrm{BA} \% \mathrm{D} 0 \% \mathrm{~B} 8 \% 20 \% \mathrm{D} 1 \% 8 \mathrm{D} \% \mathrm{D} 0 \% \mathrm{BB} \% \mathrm{D} 0$ $\%$ B5\%D0\%BA\%D1\%82\%D1\%80\%D0\%BE\%D1\%8D\%D0\%BD\%D0 $\% \mathrm{~B} 5 \% \mathrm{D} 1 \% 80 \% \mathrm{D} 0 \% \mathrm{~B} 3 \% \mathrm{D} 0 \% \mathrm{~B} 8 \% \mathrm{D} 0 \% \mathrm{~B} 8 \% 20 \% \mathrm{D} 0 \% \mathrm{~B} 2 \% 202015 \% 2$ $0 \% \mathrm{D} 0 \% \mathrm{~B} 3 . \mathrm{pdf}$

[8] Eurasian Economic Commission, Energy statistics for 2017: Genera indicators of the gas industry of the EAEU Member States (billion cubic meters), 2017. Retrieved from: http://www.eurasiancommission.org/ru/act/energetikaiinfr/energ/energo _stat/Documents/\%D0\%BE\%D0\%B1\%D1\%89\%20\%D0\%BF\%D0\%BE $\%$ D0\%BA\%D0\%B0\%D0\%B7\%D0\%B0\%D1\%82\%D0\%B5\%D0\%BB $\% \mathrm{D} 0 \% \mathrm{~B} 8 \% 20 \% \mathrm{D} 0 \% \mathrm{~B} 3 \% \mathrm{D} 0 \% \mathrm{~B} 0 \% \mathrm{D} 0 \% \mathrm{~B} 7 \% \mathrm{D} 0 \% \mathrm{~B} 0 \% 20 \% \mathrm{D} 0 \% \mathrm{~B} 7 \%$ D0\%B0\%202017\%20\%D0\%B3\%D0\%BE\%D0\%B4.pdf

[9] E. Vinokurov, P. Balas, M. Emerson, P. Havlik, V. Pereboev, E. Rovenskaya, A. Stepanova, Ju. Kofner and P. Kabat, "Futures of energy in Eurasia in a global context," 4th Workshop Report, 2016. Retrieved from:

http://pure.iiasa.ac.at/id/eprint/13966/1/Futures\%20of\%20energy\%20in $\% 20$ Eurasia\%20in\%20a\%20global\%20context.pd 